\title{
Assessing the Potential for "Cultural Disruption" through Sharing Economy: A Case Study of a Time Bank in Helsinki
}

\author{
Tomas Träskman, Nathalie Hyde-Clarke \\ Department of Culture and Communication, Arcada University of Applied Sciences, Helsinki, Finland \\ Email: tomas.traskman@arcada.fi
}

Received 27 April 2016; accepted 12 June 2016; published 15 June 2016

Copyright (C) 2016 by authors and Scientific Research Publishing Inc.

This work is licensed under the Creative Commons Attribution International License (CC BY).

http://creativecommons.org/licenses/by/4.0/

(c) (i) Dpen Access

\begin{abstract}
A better networked society has the potential to facilitate utopian ideals that embrace modes of sharing economy through the advent of the better utilization of community resources. Much has been expected of new digital communication spaces capable of linking individuals with each other outside the ambit of governments and mega-conglomerates. However, due to evolving corporate and marketing strategies, and national legal frameworks, there has been no clear demonstration of a truly alternative economic system. The recent interest in collaborative or sharing economy calls attention once more to this potential. This article presents and analyses a time-banking initiative, Stadin Aikapankki, in Helsinki, Finland. It explores the motivations behind the formation of this sharing economy community initiative, how it relates to and is expressed in terms of utopian aims and ideals, and whether this case study is able to maintain aspects of cultural disruption in the face of pressures from mainstream national actors.
\end{abstract}

\section{Keywords}

Time Banks, Sharing Economy, Cultural Disruption, Utopia

\section{Introduction}

Faced with the ecological and economic crisis, plurivocal utopian aspirations in different corners of the earth are stating the possibility of a number of alternative worlds to the present one. There are new production technologies available, there are new ways of social interaction and collaboration, and there are new ways to finance a range of activities and initiatives. The challenge is "how to connect these dots" [1]. A new order of smart, small-scale, decentralized and self-reliant economic entities is presented as an undoubtedly better and more de- 
sirable world then the "old" world dominated by mega-corporations and bureaucratic organizations. There is much debate about changing notions of ownership of assets in light of technological advances that facilitate the ability for multiple parties to utilize items such as cars and accommodation by dealing directly with the public, removing the need to engage with established commercial partners. Instead, individuals interact directly with communities or owners of the asset required, and negotiate reimbursement for the use of the item or service. This reimbursement may not necessarily be cash, but in some cases may be the exchange of other required services, time or other goods. This phenomenon has been labelled with three main terms: sharing economy; collaborative economy; and collaborative consumption. In all cases, those in support of the trend cite "access trumps ownership". This article explores the motivations for a sharing economy community initiative in Helsinki, how it relates to and is expressed in terms of utopian aims and ideals, and whether this case study is able to maintain aspects of cultural disruption in the face of pressures from mainstream national actors. The case study is a timebanking community, Stadin Aikapankki, located in Helsinki, Finland, and it is their aspirations and experiences which inform the article. In this instance, we argue that the time bank offers a good example of a desire for change, the subjection to the "otherness" of a different world, and the struggle to facilitate the emergence of a new shared understanding of economic transactions. Building on [2], we conceive of time banking as an "originator". A further argument for this contextualization is that it is in accord with the political reality in Helsinki, where time banking has been integrated into the strategic discourse of different government actors in Finland interested in sharing economy and city activism.

A common adage maintains that "time is money". Based on a notion that even a second has some monetary value, entire systems have arisen whereby the amount of time given to a task can be financially quantified, and the amounts awarded hinge on the perceived value of the person's status, tasks or services. So, for example, in this system, a doctor's or lawyer's time is charged by the hour, and may be rated more highly than that of a full-time "unemployed" parent- even though in certain cases, the value of the latter may be perceived to be higher in social and familial terms. Of course, the system is not a simple one. A profession's value is also affected by length of education received, skill set, market dynamics, labour laws, income negotiations, trade unions etc. Regardless of those mechanisms, the main point of this opening argument is that currently people perceive the time of others to be of importance and worth, based on their understanding of the contemporary system of exchange and their need of that person's skills and knowledge. In the past, individuals would often have to negotiate with larger corporations for those services. The time they would require to meet their needs would cost more given the number of "add-ons" such as agency fees, administration costs, transport and so forth. But, what happens if those barriers were removed? What happens if it were possible to create a significant change in the system whereby people were able to meet their demands by dealing directly with other individuals, and at the same time creating a transaction of services that no longer relied on monetary exchange or interfaced in a different way with existing labour law or tax parameters at the national level? Time-banking offers just such a potential. Individuals offer or seek support from others, in the belief that they too will be given someone else's "time" when it is needed, or that they in some small way contribute to or build a better community for others and themselves.

\section{Time Banking}

A global economic recession has resulted in various cutbacks in government spending at the same time unemployment rates increase and more pressure is exerted on social welfare systems. The structural changes in the global economy has resulted in an economic recession in many countries, including Finland. Faced with an aging population, a 70\% energy dependence, general geopolitical changes and political challenges, Finland (like much of Europe) has apparently entered into a phase of "degrowth" [3]. The broader economic and political discourse is one where these structural changes have been largely ignored in greater government strategies. It seems therefore unsurprising that national government agencies would request business, non-governmental agencies and community groups to become more involved in capacity building and self-help programmes. Finland has followed the trend, and the discussion around different social enterprises has quickly gained momentum. Sharing economy is beginning to be positioned as a policy solution to social innovation by different government bodies. In Helsinki, a variety of sharing economy initiatives, such as the successful "Restaurants day", represent that social innovation with international impact. This in its turn has led to a number of meetings for The Committee for the Future (a standing committee in the Parliament of Finland) with sharing economy as a topic. Time 
banking has been integrated into this strategic discourse. While the notion of geographically located or familial communities sharing resources is traditional and in some cases, an accepted practice, the rise of media technologies has widened the understanding of the term "community" and grown the range and diversity of resources available. Social inclusion policies that focus on individual behavior, rather than on social structures, create opportunities and pressures for a more active citizenry that builds social capital through informal networks and the distribution of knowledge and skills [4]. In order to have some measure of effectiveness, the argument continues, these new opportunities usually rely on people who have usually fallen outside mainstream economic initiatives or who would not normally participate: the elderly; the youth; the unemployed; ethnic minorities; and in developing states, women.

Sharing economy straddles the middle ground between economic and social activities, as well as the public and private realm [5]. Although there is increasing interest in how to access and activate additional resources within communities, the variety of applications and different perspectives of how it may be applied means that there is no set academic definition of the phenomenon, but rather a general consensus and understanding of how it may function. Seyfang argues that three aspects seem endemic to social economy: volunteers; community; and social enterprise. In this case, social enterprise refers to organisations who are primarily interested in investing in the community, rather than being driven by profit-making. It may be used to apply to the work of charities, cooperatives, and community or grassroots networks. While some may argue such practices offer an alternative to mainstream economy, this may only be an illusion, as most social economy activities still rely on the public sector for support and the private sector for trading purposes.

Thus, despite being in existence for more than three decades, manifestations of social enterprise, such as time banks, continue to suffer from a lack of more than verbal support from institutional actors, and instead rely on the goodwill of participants. Regardless, political figures and policies have identified these enterprises as a means of addressing failing or overburdened national systems, claiming that such activities may address a long list of public demands. As noted above, the political discourse in the Nordic countries has shifted from the use of the term "social enterprise/entrepreneurship", as a means to meet these public demands, to the use of "sharing economy.” These demands include, but are not limited to: a strong focus on service users' needs, specific knowledge and expertise development, flexible and "join-up" service delivery exchange, building a sense of community "ownership", the lowering of entrepreneurship risks while increasing independence to innovate, lowering consumption through sharing resources, activeness of previously unemployed, increased participation and the building of social capital through increased levels of trust [6].

Time banks are usually community-based volunteering schemes that rely on individuals giving and receiving services in exchange for time credits. They are inspired by the "time dollar" work of Edgar Cahn in the 1980s. The book, No More Throw-Away People [7] indicates that this system should be considered as a fundamentally different economy based on home, family, neighbourhood and community partnerships. It emphasises the importance of co-production as a process, a value system and a set of standards that prioritises people as assets. As such, co-production could be viewed as an "antidote" to counter the human costs of a capitalist, materialistic world. It could instead restore dignity, confidence and "usefulness"- thus improving the interaction and efficiency of service exchange.

At its most basic, one hour of work is equivalent to one time credit. Different schemes follow different criteria for how the time credits may be exchanged. They literally range from pure volunteer work where no return for services rendered is expected, to a direct reciprocity relationship where the amount of time put in is the equivalent of time that may be requested (taken out). As with any form of currency, time credits may be banked, donated, gifted or redeemed immediately for services from other members. Seyfang argues that the advantage of having time credits separated from monetary exchange is that it is still possible for cash-strapped communities to participate. The service exchanged tend to be everyday skills and fall within ordinary parameters of daily life: a lift to work or the shops; gardening; babysitting; walking the dog; small household repairs etc. There is an obvious limitation to this type of collaboration, during periods of economic growth, more skilled members are unlikely to participate with lesser skilled participants if there is a chance of receiving monetary compensation, and so in those situations, trade between equally skilled partners would be more likely to succeed.

While media technologies would in essence allow anyone to participate, given the nature of the community, in order to work, members should be able to access services and assist when needed. Expanding a time bank beyond a specific geographical location could be difficult as it is the physical proximity that allows for the bonds to be created. Although, Valek and Jasikova consider cognitive proximity to also be important for the in- 
itiative to succeed. As a result, time banks tend to form around locally based communities in a prescribed location with like-minded individuals. It requires the organizational services of a "time broker" who is responsible for recruiting members and maintaining the membership list. The broker also provides a database of available services, and captures or records the time credit balances of members. Again schemes may have slightly different approaches to how individuals participate. In some instances, all communication between members is handled by the broker, who behaves as an agent. In others, members are able to access each other's contact details and communicate directly.

It is important to note though that while time banks may improve neighbourly relations, little evidence seems to show actual economic support, growth or empowerment-unless those are the actual objectives of the group in question [8]. Arguably though, the engagement and participation in time banks may encourage individuals to either recognize a niche in the market and start their own business enterprise, join or rejoin the mainstream workforce due to the acquisition of skills, the identification of community needs, improved self-esteem and stronger social networks. As such, those experienced in the operations of time banks recommend the importance of first building self-belief and confidence amongst individual members around the notion that everyone's time is of equal value and all can contribute meaningfully. In larger groups, counsellors may be assigned to encourage members to appreciate their worth, and boost their participation and range of offered services.

Emphasis must be placed on how "work" and "market value" is defined both by the community and broader society. The principles of time banking recognize people as assets, refine "work" to include core activities that usually go unpaid in a community, and build on a foundation of reciprocity and mutual benefit [9]. A value system is thus based on "a schema of incentives, trust building and management, ethical code, the collaborative network organisation culture, and contracts and collaboration agreements" and "the ordering and prioritising of a set of values that an actor or society of actors holds” [10]. It should therefore be subjective, normative, dynamic and to a large extent, measurable. In sharing economy, attempts have been made to observe and analyse transactions between members in terms of frequency of input, satisfaction of outcome and rate of reciprocity. This is often achieved by first identifying a common element or regulation, so for example in time banks, the common unit is one hour. Participants are plotted as nodes in an interconnected network, and the size of the node is dependent on the number of interactions and hours exchanged. Through the aforementioned study, it is possible to hypothesize that there is a direct correlation between the satisfaction of a participant and the likelihood that the participant will continue to engage with the community. However, an interesting component is that these more quantitative studies of reciprocity do not always explain why some individuals may continue to engage with sharing economy activities even if they believe that they do not receive services of value from the collaborative community, or know from previous experience that they could find better services or goods elsewhere. Arguably, "social responsibility" or altruism may sometimes not account for the "need to belong” or if that participation has been motivated by an interest in social activism or change-another significant factor to consider.

The main goal of such initiatives is to meet the needs of a community by ensuring that all may participate to the betterment of the group. Knapp et al. refer to this as the effectiveness aim, which in addition to a cost-effectiveness aim ensures that the best outcomes are achieved from all available resources. It is possible to establish how efficiently resources are being used through traditional cost-effectiveness analysis techniques-at its most basic, a comparison of what goes in versus what comes out. However, given the nature of time banks, it may not be feasible to assign economic values in order to determine benefit to community. Instead, researchers face the challenge of identifying different subsets of values to demonstrate effect.

As part of emotion-based values, members should not feel that their time is exploited or abused by those who see it as a means of gaining labourers while avoiding the paying of wages, or by governments who see it as a possibility to replace public services. Much of the excitement around time banks and (currently) sharing economy is about how they may change the way that people interact and cooperate with one another. In order to rework our high consumption, social aspects of the new worlds and orders created should also be embraced [11]. So too is this relevant for emerging cultural policies and trends. It is also important to note that the general reluctance to accept these sharing economy initiatives into the mainstream economy may be attributed in some part to a concern that they may appear to be too utopistic.

\section{Method}

Our research method is based on a case study approach. We begin by identifying utopianism as a hermeneutic theoretical attitude to help explain social life and apply it to the phenomenon of time banking as a reaction to 
mainstream commercial practices. We then refer to a case study in order to address our hypothesis that this time bank, could, under certain conditions, represent a cultural disruption as described by utopian authors. It has been proposed that utopia be used to make explicit the kinds of society implied in existing political programs and constructing alternatives. This builds on H.G. Wells' argument from 1906 that the creation of utopias is the proper and distinctive method of sociology, and suggests that utopia as a method entails "also considering the kinds of people we want to become and that different forms of society will promote or inhibit” [12]. The Helsinki time bank, Stadin Aikapankki, is chosen as the case study due to the unique and innovative position the organization had adopted at the time of our study in terms of their time-tax initiative.

While case studies are usually associated with the evaluation of processes, they may also prove useful when used to analyse the outcomes of interventions and thus this research may be defined as: "an empirical enquiry about a contemporary phenomenon (e.g. a "case") set within its real-world context—especially when the boundaries between phenomenon and context are not clearly evident" [13]. Thus the context and conditions in which the case appears, is essential to its understanding. In this way, case study research offers a greater consideration of social norms, rather than a mere analysis of an isolated unit or variable. Therefore this research takes its evidence from multiple sources, including indepth interviews with the broker of the time bank that were conducted over a period of time, content analysis of the online material generated by the time bank, the consideration of the findings of recently published studies about time banks in Finland, and the examination of relevant government policy papers.

It is not be surprising that previous time bank studies are informed by rich qualitative studies that consider process, as well as outcome. In these instances, outcome may not be apparent for a number of years, in which case, effectiveness may only be assessed in terms of current or past perceptions of experience and individual behaviour. This study is embedded in this approach. As such, while the findings may not be generalised according to scientific research understandings, they do offer valuable insight into this social enterprise's actual and intended impact in society.

\section{Cultural Disruption and Utopian Premises}

Positively put, time banks and similar social enterprises enjoins us to search for meaning in the immanence of collective life, where shared existence is interpreted each time anew. This is the reality that "agents of alternatives" such as Shareable, are trying to reveal when they write about a "movement of movements", or for example, commons.fi, urges us to recognize all the alternative economic practices around us that the mainstream economic thinking is trying to ignore. But while these agents of alternatives see themselves as firmly grounded in reality, its critics recast the practices in the banal guise of idealism, and utopia-as in "impossible". It is tempting to read the sharing economy in line with the totalizing grand narratives of the past that tell about failed utopias. And, looking at the popular debate around the sharing economy it would also be easy to presume that what we experience today is not a radical disruption in late capitalism, but simply another colonization by capitalism. The sharing economy runs the risk of becoming a "new map to hell", yet another addition to utopias turned to dystopia. In the raging debates around sharing economy, this development is referred to as sharing economy being incorporated by the business-as-usual economy or part of New Age Capitalism [14], or Neoliberal Socialism [15]. There is evidence to show that aspirations to a low-cost sharing community are being thwarted by the hard realities of the commercial world. The peer-to-peer economy is receiving more criticism in the wake of recent trends. People buy cars to rent, and inhabit larger apartments knowing that they can lease unused rooms at higher prices [16]. More large corporations enter the sharing economy space in order to recapture their dwindling or threatened consumer base. Entities operating in this largely unregulated space have been accused of exploiting workers as unfettered competition drives down hourly wages and social benefits no longer apply [17]. "Sharewashing" [18] has been called out as a term to describe this exploitation, in which platforms shift risk onto employees, and for-profit platforms coopt what began as a progressive, utopian, socially transformative idea.

At the same time, those who were originally attracted to the ideal of "making a difference" have actively demonstrated their dislike of more corporate practices in this space and publically deleted apps designed for this purpose. Whether these numbers reach a capacity deemed significant to those operating in the system, creating a review of current practices, remains to be seen. The tragedy of so many utopian experiments of the past, is when the "alternatives", (in this case the pro-sharers) uncritically and blindly adopt the interpretations imposed by the same hegemonic ideology they aim to overthrow. Sharing economy, runs the risk, of being incorporated into "cynical realism": "the empty ideology that accompanies the practices of profit and money making, and that has 
(and needs) no content to disguise itself” [19]. Cynical realism states, according to this argument, that no alternative is possible. Transformation, and space for agency that could bring about change, is simply not recognized in the cynical perspective. So what the cynics observe, in the "break" that the sharing economy is trying to imagine, is simply wishful thinking. In order to counter this universal ideological conviction a new discursive strategy is introduced: disruption. Accordingly, we have to force ourselves to imagine the break itself, that radical difference is possible and that a break is a necessary intervention.

A majority of the growing debate and reflection on the sharing economy involves disruption, the idea of a break with the present, referred to as the "phenomenalisation" of the crisis [20]. A phenomenalisation makes evident that the deficiencies, wrongs and injustices in the world are not sheer accidental occurrences in an otherwise smoothly functioning totality, but are constitutive of the political and economic organization, dependent on these very injustices. The narrativisation of the sharing economy starts from a profound sense of dissatisfaction with the present, (heralded as being the equivalent to even battle cries), and continues with different descriptions and imaginaries of contemporary, grassroots social movements that seek to reclaim democratic control over the conditions of existence. So when [21] describes us as being in a “critical juncture”, she is displacing herself in the utopian break, in a liminal space, between the old business-as-usual world, and something else. However, a "critical difference" needs to happen. What this critical difference, or break, is, remains unclear. The author refers to "an enormous new economic value", being created in the sharing economy, and a "hunch" that an openness to and ideally connection with other social movements outside the United States could harness the power of sharing. Regarding the discourse of the sharing economy, the argument continues that the critics are too cynical, while the "pro-sharing discourse is blind to the dark side of these innovations". It would be correct to address the need for more nuance. Simplification is common in the sharing economy debate. It is also striking how AirBnB and Uber dominate the debate as the examples that embody the sharing economy. This dilemma is highlighted by [22] when there is a conclusion that any talk of true "collaboration" in the "collaborative economy" is impossible since: "What leads those discussions? Uber, Lyft and Airbnb. When we hear about how big their footprint is, those numbers include Uber, Lyft and Airbnb. When we talk about the financial aspects of the market's size, who comes up again? Uber, Lyft and Airbnb”.

Put into a historic context much of the contributions to the debate echo the many clashes between cold realism and dangerously fanciful brands of idealism that is a common tension that has marked all processes of social transformation in the modern era [23]. These narrative strategies run a risk limiting alternative forms of thinking and talking, as they create mere caricatures instead of documenting real individuals, practices and institutions. But what are the experiences of the practitioners of the sharing-economy? Can levels of agency be registered in terms of opposition on this local level?

Some evidence shows that the practitioners of the "sharing economy", are not acting as docile bodies who blindly endorse either capitalism (or anti-capitalism), the operations of the market, or business-as-usual. A study on time bankers [24] revealed that the transformational potential of time banking was inhibited when participants reverted to internalized habits of capitalist exchange, while the presence of innovative exchange logics suggested the emergence of new economic relations in which interpersonal connection was central. A complex identity work involving appropriation, opposition and identification, as well as dis-identification seems to exist on the local level of practice. The emergence of a new set of semantic coordinates for the sharing economy, the re-signifying of the life-world of the sharing community, puts that community into a position of fragility, precariousness, where, to put it in utopian terms, power is exercised without domination. A study of this could reveal agency and resistance as it is perpetuated and rearticulated in novel ways, as well as give insights into practitioners' reflections on difference, and the "break” with business-as-usual. In order to produce new knowledge, we, in the next section, examine one of these communities as they perform disruption as they try to exist in the liminal space created by their perceived break with reality. In this way we hope to project the utopian individuals of the sharing community with what Jameson refers to as "concrete existential density".

\section{Case Study: Stadin Aikapankki in Finland}

In October 2009, a Finnish time bank, Stadin Aikapankki, was established in the Helsinki area. The organization originated from a spontaneous discussion between neighborhood friends about their general dissatisfaction with the failure of global forums, such as Climate Change, which they attributes to a lack of sufficient political will to transform existing systems and markets. At the same time, there was a growing awareness of dialogues around the world addressing ideas of "different” currencies. This small group of members, had, in search for active ci- 
tizenry in their district of Kumpula, stumbled on the format of time banks. Time banking resonated well with the group's aspiration to create alternatives to the capitalist economy. In light of this common concern, the group, represented by Ruby Van der Wekken, met with other like-minded organizations and social groups, and naturally turned to the possibility of using time as the lowest currency where all would be equal. One time hour was identified as a "Tovi" and the manner in which it could be acquired or banked referred to as Tovi-etiquette [25]. It was quite a "radical" way of thinking at that moment, and one to which the members of the group could ascribe. Utopian desire met utopian form, and in this process the media technology and infrastructure for the distribution of knowledge, skills and informal networking was already there since Stadin Aikapankki could use the existing interface of Community Exchange Services (CES). This led to a relatively rapid growth of members, and transactions in the time bank. The skills offered in Stadin Aikapankki are mostly everyday skills (such as childcare, party planning or sewing), but this can be explained by the existence of a parallel time bank, called Aika Parantaa (translation: time heals), which offers a "low threshold system of peer support for those situations when life takes a dip to worse" [26]. It was therefore possible to offer exchanges beyond social health services.

From the start, members identified the main objective of their organization to be about "change", not need. An aspiration was to change the current, market-related systems due to what was attributed as the "unhappiness it breeds socially... creating huge inequalities". They intentionally chose to use the name pankki (translation: bank) in order to demonstrate the possibility of alternative currencies and at the same time interrogate the functions of the traditional institutions. There was thus most certainly a desire to create a cultural disruption.

Common "values" were identified as being in need of discussion and agreement. A series of workshops were held with the then twenty members. It was also necessary to discuss who could join, as already at that stage smaller commercial actors had realized the potential of time banks for their own profits, and the group wished to completely avoid this association. It was also agreed that members should be in close geographical proximity as the time bank would not work well if people were too far apart: "then you cannot have a system that is meaningful". Objectives and values were then posted online, with a background to time banks and the desires of this group [27]. On that website, the membership group addresses mutual concerns such as reciprocity, economic justice, and the "we-spirit". However, upon later reflection, there is now a realization that perhaps they were too flexible in their collective understanding of those principles and aspirations in terms of purpose and function of the group, as when under pressure it was very difficult to maintain a sense of cohesion.

At the time of this research, the time bank had recently experienced the position of fragility, and precariousness caused by its break with traditional society in very concrete terms. An institutional actor, more precisely the tax-authorities, had taken an interest in their operations. A factor that contributed to the absence of "skilled labour" in annual reports had raised questions about the need to regulate time banks in 2012. In a statement from 2013, the tax-authorities presented their view on the transactions of time banks, and concluded that the transactions were taxable since the work involved compensation [28]. They also stated that even though the time banks were much discussed in media, the tax-authorities in Finland did not consider the time banks as a priority in the fight against the grey economy ${ }^{1}$. Van der Wekken argues that the public attention, and especially the association to the grey economy, had dire consequences for the community in the form of decreased activity, engagement, and new memberships: "the guidelines are confusing... you have to pay taxes on what that service would cost in the market. It has had a big effect, and that is a pity". Uncertainty as to whether the community was a part of the grey-economy created alienation and dis-identification. Grey economy, tax evasion, and tax paradises are, after all, generally perceived as ways to protect ones private property, and have little to do with collective solidarity. The other problem, according to Stadin Aikapankki, was that the tax-authorities sidestepped the basic principle and value-ground of time-banking, i.e. that everyone's time is equal.

In France, something similar had happened, and pressured by the tax-authorities, the French time banks had decided to separate "skilled work" from the transactions offered in the time banks. Skilled work was subject to tax. This division was however in conflict with the equality principle, but also with the original aspiration of Stadin Aikapankki: to create alternatives to capitalist economy. Stadin Aikapankki proposed a complementary solution in the form of a "time tax.” In a letter to the Helsinki City Council, Stadin Aikapankki proposes that the time tax could be a part of the tax system of the public administration, which, in its turn, could help the city in its strategy to become a pioneer in "glocalisation". Peltokoski et al. base the time-tax on the idea of communing

\footnotetext{
${ }^{1}$ The Finnish Tax Authority uses the following definition: "The grey economy means such activities of an organisation in which the organisation fails to meet the statutory obligations arising from its operations so that the payment of taxes, statutory pension, accident or unemployment insurance contributions or the fees charged by the Finnish Customs can be avoided or unjustified refunds received” [29].
} 
and the principle is when the provider of a service receives time-credits, a percentage of the time-credits earned are automatically transferred to the account of an ethical economic actor of choice: examples could include a food cooperative, another local CSA, or the Aika parantaa network. Accordingly, the time-tax function lets time bank members strengthen similar purposed actors and organizations that exemplify the values listed in the ABC of Stadin Aikapankki's homepage. It also supports work that is important to its own time bank members, while strengthening and developing the greater community. In a larger context, the time-tax and time-credit can be seen as ways that the time bank supports solidarity economy building, and the Commons in Finland.

For this community, the time tax certainly represents a re-signification of the life world of that community, and an attempt to reach a position of not only resistance but also agency. Members of Stadin Aikapankki and researchers present the tax authorities as the main obstacle to sharing economy initiatives, and suspects that "the guidelines are intended to prevent time banking from growing and challenging the dominance of both market and state, and the capitalistic order itself” [30]. A less cynic relationship between time bankers and the government is presented in a report [31]. A survey on active users of the timebank shows that many users actually perceived the statement of the tax authorities as a good thing, since it "pushed them to find other solutions" [32]. The time bank now agrees that they need to look at other ways of changing market systems. Aside from the negative influence of the tax policy, there is a feeling that time banks are now too "mainstream" to be effective, according to Van der Wekken: "they are not so innovative now, they are entering corporate social responsibility models”. There is an acknowledgement that they need to rethink their purpose, and get a step further in order to continue. As part of this process, members have attended international forums, and participated in joint discussions with other Finnish social actors in efforts to find a common platform that will support an alternative system (the platform, Another Financial system \& Money for Finland, has meetings once or twice a month winter 2015-2016), as well as to create a working tool or framework that can help build stronger structures without becoming too institutionalized. While the group agreed that "community should be put at the forefront", there was a genuine need for more critical reflection about what is being done, why it is being done and what is expected from political or government actors who often view these systems quite differently from the people involved.

\section{Concluding Remarks}

In this study, we have aspired to give the research on time banks a novel twist by relating it to the question of (utopian) cultural disruption. We thereby purport that the desire for, and imagining of, a break, as well as the practice of alternatives, is inherent to contemporary processes of representation of both the established order and the mobilising forces that have the potential to overturn it. The agents of alternatives demand that the established order be faced with a representation. These agents portray both the language of power and domination, and the possibility of forces of change and mobilization. Time banks, and other examples of social enterprises, imply a type of political, social, and economic organization that does not take place in society as it is legislated, and that have not found their space in this society, but still relate to the society by portraying and projecting ways of living which do not yet exist. We have pointed out that, although there is a call for disruption, new semantic coordinates are rare, and much of the debate focuses on the representation of the "hegemonic" order. Our case study, Stadin Aikapankki, offers in its "time-tax" as an example of how poetics, and the poetical side of representation, could open up new worlds. These worlds are not replacing the current reality, but are imagined as parallel worlds, creating an idea of a society of multiple or plural ontologies. The time bank's blueprints for the building of a better community for others and themselves, are based on the idea of plurality. The established order, for example the city government, interested in "a potential of mobilising forces that offer bettering of social groups", should recognise the frailty inherent in these alternative economy initiatives. Stadin Aikapankki, is a good example of how the interest shown from government and private bodies is interpreted as a desire to instrumentalise and commercialise, the potential social transformation created in these communities.

Does this time bank then offer evidence as a beginning of a "cultural disruption” as defined in the earlier sections of this article? Certainly there they have been able to move beyond existing parameters. More importantly for this path of enquiry, unlike other ventures established to address flaws or weakness in various social services systems, this group founded its practices based on the very real desire to seek change and find alternatives to an established global commercial system. And for a while they were able to disrupt familiar, usual and expected practices until external pressures from the over-arching national structure created imbalance in their community, and fractured common purpose or understanding, resulting firstly in disarray, and then in a return for many 
members to the status quo to accepting the larger more encompassing norms.

Is it then possible to maintain these practices given economic pressures of the international and national actors? In order to do so, this study demonstrates that the goodwill of participants is vital, provided scaling-up does not fracture and defuse efforts. The perception of the founder of Stadin Aikapankki also indicated that there was a tendency to lose momentum when the group had diversified objectives or failed to have collective consensus around goals and aspirations. Stadin Aikapankki's unwillingness to identify with broader understandings of the sharing economy and ideas of scaling-up as a necessary step to achieve their emancipatory ambition, can be read as an attempt to keep the field of signification open. The collision with the tax-authorities and the resulting suggestion of a time tax could well produce very interesting solutions for future challenges that still remain true to the tenets of the Nordic welfare state.

\section{References}

[1] Oosterman, A. (2015) Intermission or Game Change? http://volumeproject.org/intermission-or-game-change/

[2] Fitzmaurice, C. and Schor, J. (2015) Collaborating and Connecting: The Emergence of the Sharing Economy. In: Reisch, L. and Thogersen, J., Eds., Handbook of Research on Sustainable Consumption, Edgar Elgar, Massachusetts, 410-425.

[3] Andersson, J. (2010) Degrowth-Hallittu Talouslasku. Talous \& Yhteiskunta, 4, 42-49.

[4] Seyfang, G. (2003) With a Little Help from My Friends. Evaluating Time Banks as a Tool for Community Self-Help. Local Economy, 18, 257-264.

[5] Seyfang, G. (2006) Time Banks and the Social Economy: Exploring the UK Policy Context. CSERGE Working Paper EDM, 6, 1-14.

[6] Valek, L. and Jasikova, V. (2013) Time Bank and Sustainability: The Permaculture Approach. Procedia: Social and Behavioral Sciences, 92, 986-991. http://dx.doi.org/10.1016/j.sbspro.2013.08.788

[7] Cahn, E. (2004) Throw-Away People: The Co-Production Imperative. 2nd Edition, Jon Carpenter Publishing, Oxfordshire.

[8] Callison, S. (2003) “All You Need Is Love”? Assessing Time Banks as a Tool for Sustainable Economic Development. Local Economy, 18, 264-267. http://dx.doi.org/10.1080/0269094032000111048d

[9] Seyfang, G. (2004) Time Banks: Rewarding Community Self-Help in the Inner-City? Community Development Journal, 39, 62-71. http://dx.doi.org/10.1093/cdj/39.1.62

[10] Abreu, A. and Camarinha-Matos, L.M. (2006) On the Role of Value Systems and Reciprocity in Collaborative Environments. In: Camarinha-Matos, L., Afsarmanesh, H. and Ollus, M., Eds., Network-Centric Collaboration and Supporting Frameworks, Springer, Boston, 273-284.

http://www.researchgate.net/publication/226037797_On_The_Role_Of_Value_Systems_And_Reciprocity_In_Collabo rative Environments

[11] Dey, P. and Steyaert, C. (2010) The Politics of Narrating Social Entrepreneurship. Journal of Enterprising Communities: People and Places in the Global Economy, 4, 85-108. http://dx.doi.org/10.1108/17506201011029528

[12] Levitas, R. (2013) Utopia as Method: The Imaginary Reconstitution of Society. Palgrave Macmillan, London, 16-17. http://dx.doi.org/10.1057/9781137314253

[13] Yin, R. (2012) Applications of Case Study Research. 3rd Edition, Sage, California, 4.

[14] Henwood, D. (2015) What the Sharing Economy Takes. The Nation. http://www.thenation.com/article/196241/what-sharing-economy-takes

[15] Davies, W. (2015) The Happiness Industry: How the Government and Big Business Sold Us Well-Being. Verso, New York.

[16] The Economist (2013) The Rise of the Sharing Economy: Peer-to-Peer Rental. http://www.economist.com/news/leaders/21573104-internet-everything-hire-rise-sharing-economy

[17] Goodale, G. (2015) With Big Growth for the Sharing Economy, Has It Become Selfish? The Christian Science Monitor. http://search.proquest.com/docview/1664945551?accountid=27294

[18] Marder, M. and Vieira, P. (2012) Existential Utopia: Of the World, the Possible, the Finite. In: Vieira, P. and Marder, M., Eds., Existential Utopia: New Perspectives on Utopian Thought, Continuum, New York, 35-50.

[19] Schor, J. (2014) Debating the Sharing Economy. http://www.greattransition.org/publication/debating-the-sharing-economy

[20] Blanchard, O. (2015) Stop Calling It the “Sharing Economy.”: That Isn’t What It Is. 
http://olivierblanchard.net/stop-calling-it-the-sharing-economy-that-isnt-what-it-is/\#.ViyQhWyTZjs.facebook

[21] Couton, P. and Lopez, J.L. (2009) Movement as Utopia. History of the Human Sciences, 22, 93-121. http://dx.doi.org/10.1177/0952695109337694

[22] Dubois, E., Schor, J. and Carfagna, L. (2014) New Cultures of Connection in a Boston Time Bank. http://www.bc.edu/content/dam/files/schools/cas_sites/sociology/pdf/SchorTimeBank.pdf

[23] Jameson, F. (2005) Archaeologies of the Future: The Desire Called Utopia and Other Science Fictions. Verso, New York.

[24] Van der Wekken, R. (2015) Interview Conducted on 24 August 2015 at Kumpula, Helsinki, Finland.

[25] Stadin Aikapankki (2014)

https://stadinaikapankki.wordpress.com/stadin-aikapankin-kannanotto-aikapankkien-verotuksesta/18-6-2014-kirje-kau punginvaltuustolle-ja-hallitukselle/

[26] Aikaparantaa (2015) http://www.aikaparantaa.net/english.html

[27] Stadin Aikapankki (2015) https://stadinaikapankki.wordpress.com/in-english/helsinki-timebanks-abc/

[28] Skatteförvaltningen (2013) Aikapankit Suomessa. Verohallinto. 4.6.2013.

[29] Vero Skatt (2014) The Grey Economy 2014.

https://www.vero.fi/download/The Grey Economy 2014/\%7BB108A9DB-3AD6-4377-8D54-47349CA2D496\%7D/1 $\underline{0269}$

[30] Peltokoski, J., Toivakainen, N., Toivanen, T. and van der Wekken, R. (2015) Helsinki Time Bank: Currency as a Commons. In: Bollier, D. and Helfrich, S., Eds., Patterns of Commoning, Leveller's Press, Massachusetts.

[31] Sanomat, T. (2015) Firma Vaihtoi Nimeään-Osake Ampaisi 10\% Nousuun. http://www.taloussanomat.fi/porssi/2015/05/12/firma-vaihtoi-nimeaan-osake-ampaisi-10-nousuun/20156047/170

[32] Eskelinen, T. (2014) Aikapankkien Yhteiskunnalliset Vaikutukset ja Verotus. Vasemmistofoorumi ry: 29. http://www.vasemmistofoorumi.fi/wp-content/uploads/2014/05/aikapankki-raportti final.pdf 